
POSTAL SERVICE $\otimes$ (All Periodicals Publications Except Requester Publications)

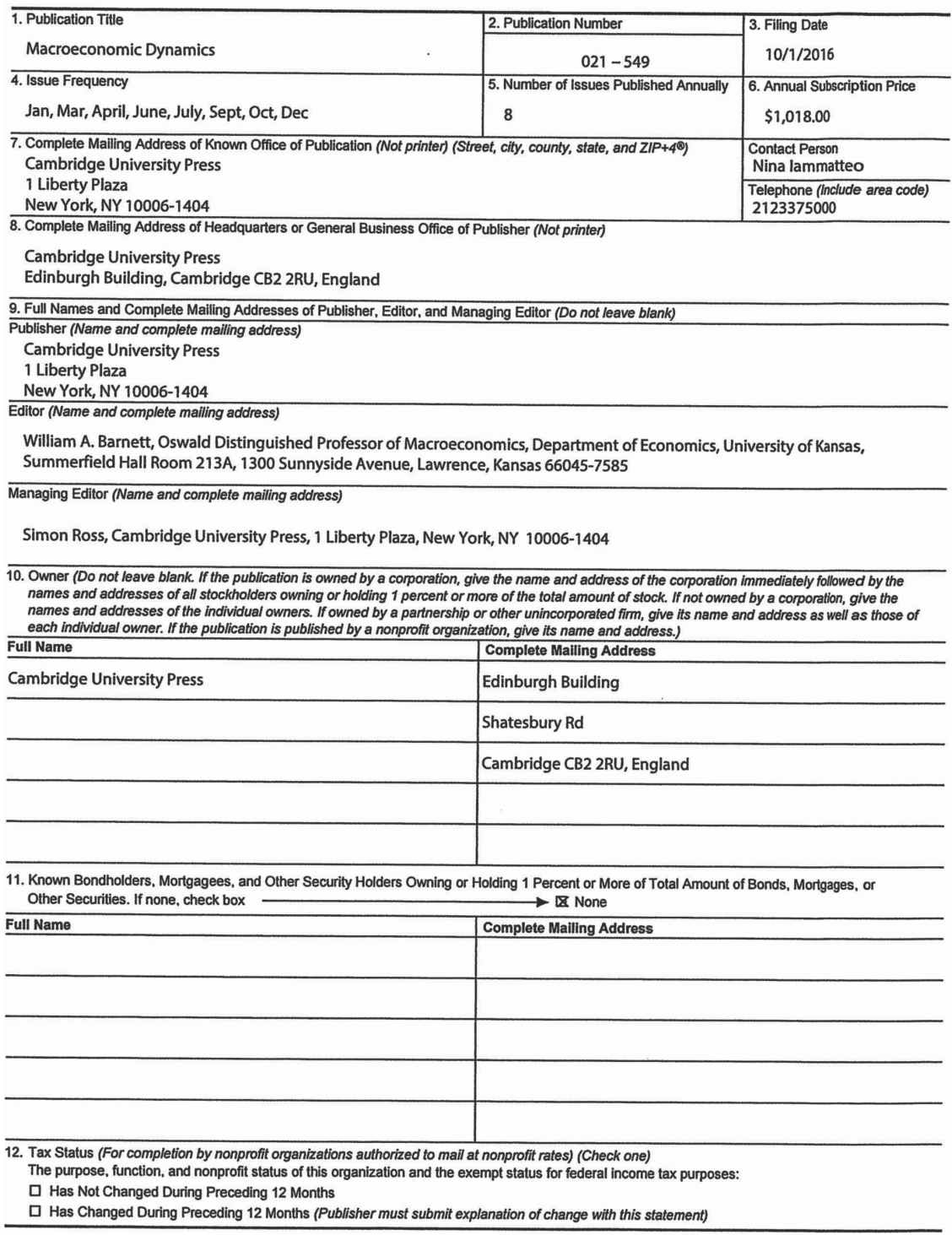




\begin{tabular}{|c|c|c|c|c|}
\hline \multirow{2}{*}{\multicolumn{3}{|c|}{$\begin{array}{l}\text { 13. Publication Title } \\
\text { Macroeconomic Dynamics } \\
\text { 15. Extent and Nature of Circulation }\end{array}$}} & \multicolumn{2}{|c|}{$\begin{array}{l}\text { 14. Issue Date for Circulation Data Below } \\
\text { JULY } 2016\end{array}$} \\
\hline & & & \multirow{2}{*}{\begin{tabular}{|c|}
$\begin{array}{l}\text { Average No. Copies } \\
\text { Each Issue During } \\
\text { Preceding } 12 \text { Months }\end{array}$ \\
248 \\
\end{tabular}} & $\begin{array}{l}\text { No. Copies of Single } \\
\text { Issue Published } \\
\text { Nearest to Filing Date }\end{array}$ \\
\hline \multicolumn{3}{|c|}{ a. Total Number of Copies (Net press run) } & & 228 \\
\hline \multirow{4}{*}{$\begin{array}{l}\text { b. Paid } \\
\text { Circulation } \\
\text { (By Mail } \\
\text { and } \\
\text { Outside } \\
\text { the Mail) }\end{array}$} & (1) & $\begin{array}{l}\text { Mailed Outside-County Paid Subscriptions Stated on PS Form } 3541 \text { (Include paid } \\
\text { distribution above nominal rate, advertiser's proof copies, and exchange copies) }\end{array}$ & 57 & 56 \\
\hline & (2) & $\begin{array}{l}\text { Mailed In-County Paid Subscriptions Stated on PS Form } 3541 \text { (Include paid } \\
\text { distribution above nominal rate, advertiser's proof copies, and exchange copies) }\end{array}$ & 0 & 0 \\
\hline & (3) & $\begin{array}{l}\text { Paid Distribution Outside the Mails Including Sales Through Dealers and Carriers, } \\
\text { Street Vendors, Counter Sales, and Other Paid Distribution Outside USPS }\end{array}$ & 107 & 112 \\
\hline & (4) & $\begin{array}{l}\text { Paid Distribution by Other Classes of Mail Through the USPS } \\
\text { (e.g., First-Class Mail()) }\end{array}$ & 0 & 0 \\
\hline \multicolumn{3}{|c|}{ c. Total Paid Distribution [Sum of 15b (1), (2), (3), and (4)] } & 164 & 168 \\
\hline \multirow{4}{*}{$\begin{array}{l}\text { d. Free or } \\
\text { Nominal } \\
\text { Rate } \\
\text { Distribution } \\
\text { (By Mail } \\
\text { and } \\
\text { Outside } \\
\text { the Mail) }\end{array}$} & (1) & Free or Nominal Rate Outside-County Copies included on PS Form 3541 & 0 & 0 \\
\hline & (2) & Free or Nominal Rate In-County Coples Included on PS Form 3541 & 0 & 0 \\
\hline & (3) & $\begin{array}{l}\text { Free or Nominal Rate Copies Mailed at Other Classes Through the USPS } \\
\text { (e.g.. First-Class Mail) }\end{array}$ & 0 & 0 \\
\hline & (4) & Free or Nominal Rate Distribution Outside the Mail (Carriers or other means) & 8 & 8 \\
\hline \multicolumn{3}{|c|}{ e. Total Free or Nominal Rate Distribution (Sum of 15d (1), (2), (3) and (4)) } & 8 & 8 \\
\hline \multicolumn{3}{|c|}{ f. Total Distribution (Sum of 15c and 15e) } & 172 & 176 \\
\hline \multicolumn{3}{|c|}{ g. Copies not Distributed (See Instructions to Publishers \#4 (page \#3)) } & 76 & 52 \\
\hline \multicolumn{3}{|c|}{ h. Total (Sum of $15 f$ and $g$ ) } & 248 & 228 \\
\hline \multicolumn{3}{|c|}{$\begin{array}{l}\text { i. Percent Paid } \\
\text { (15c divided by } 15 f \text { times 100) }\end{array}$} & $95 \%$ & $95 \%$ \\
\hline \multicolumn{3}{|c|}{ 16. Electronic Copy Circulation } & $\begin{array}{l}\text { Average No. Copies } \\
\text { Each Issue During } \\
\text { Preceding } 12 \text { Months }\end{array}$ & $\begin{array}{l}\text { No. Copies of Single } \\
\text { Issue Published } \\
\text { Nearest to Filing Date }\end{array}$ \\
\hline \multicolumn{3}{|c|}{ a. Paid Electronic Copies } & 0 & 0 \\
\hline \multicolumn{3}{|c|}{ b. Total Paid Print Copies (Line 15c) + Paid Electronic Copies (Line 16a) } & 164 & 168 \\
\hline \multicolumn{3}{|c|}{ c. Total Print Distribution (Line 15i) + Paid Electronic Copies (Line 16a) } & 172 & 176 \\
\hline \multicolumn{3}{|c|}{ d. Percent Paid (Both Print \& Electronic Copies) (16b divided by $16 \mathrm{c} \times 100$ ) } & $95 \%$ & $95 \%$ \\
\hline
\end{tabular}

Q I certify that $50 \%$ of all my distributed copies (electronic and print) are paid above a nominal price.

\section{Publication of Statement of Ownership}

\If the publication is a general publication, publication of this statement is required. Will be printed in the December_ issue of this publication.

18. Signature and Title of Editor, Publisher, Business Manager, or Owner

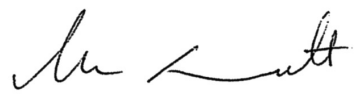

I certify that all information furnished on this form is true and complete. I understand that anyone who furnishes false or misleading information on this form or who omits material or information requested on the form may be subject to criminal sanctions (including fines and imprisonment) and/or civil sanctions (including civil penalties). 


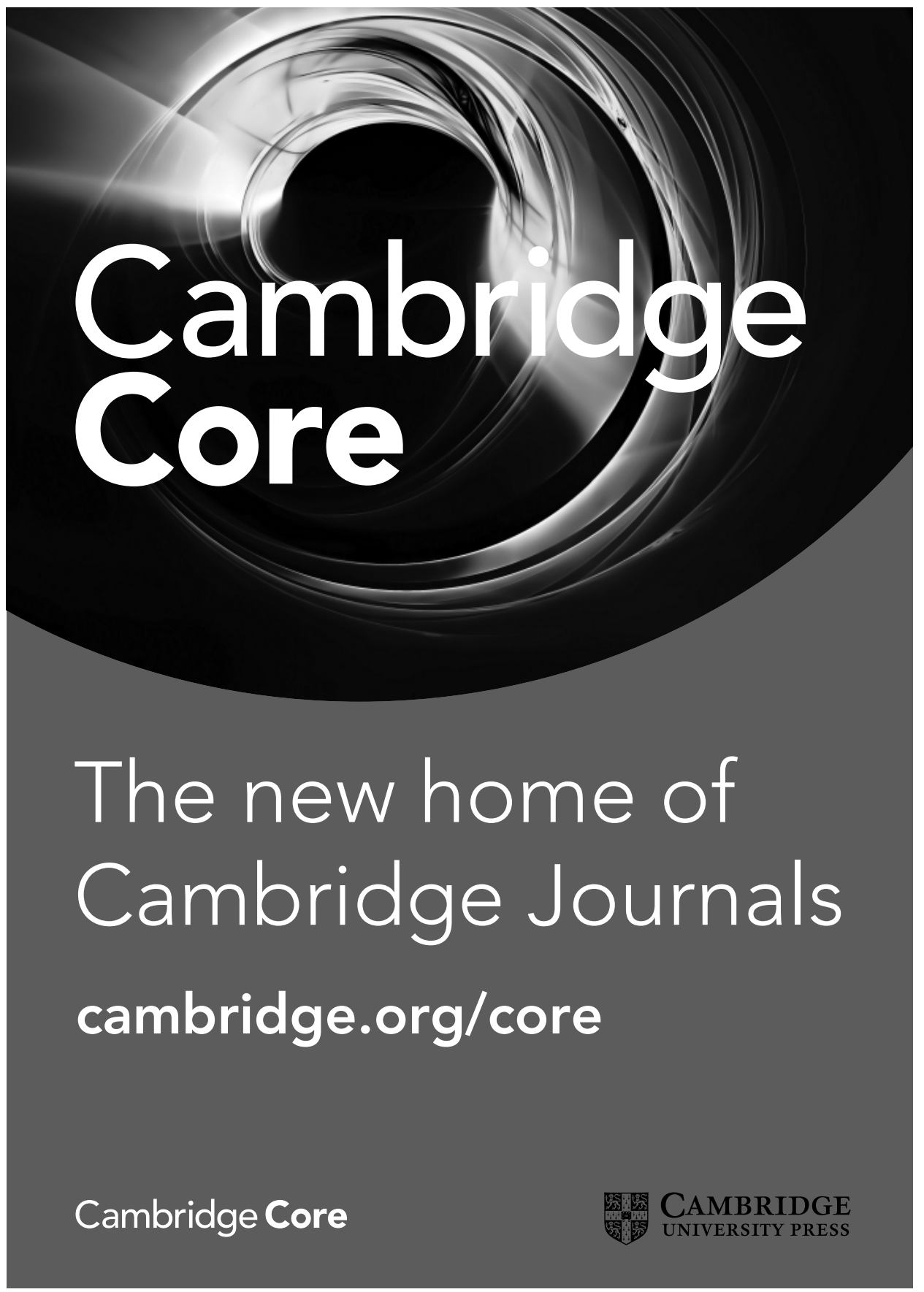


Contributions. Contributions are welcome from all countries. They should be written in English.

Aims and Scope/Editorial Policy. Macroeconomic Dynamics publishes research of the highest theoretical, empirical or quantitative sophistication. Papers of high quality are welcomed from all areas of macroeconomics and from all parts of the world, as long as the research is founded in a rigorous scientific approach. Major advances in macroeconomics without immediate policy applications are also accepted, if they show potential for application in the future. Occasional book reviews, announcements, conference proceedings and interviews are also published. Special issues appear in the journal's Supplements Series, having its own Special Issues Editors. An electronic version of the journal will be published simultaneously with the paper version enabling immediate access to the best current research in Macroeconomics.

Home Page. The journal has a home page on the web which is a source of further information about the journal. The location of the home page is: http://econ.tepper.cmu. edu/barnett/MD.html. Information. about Macroeconomic Dynamics may also be viewed at www.journals.cambridge.org.

Manuscript Submissions. The submission procedure for this journal has been converted to electronic uploading of pdfs to the journal's server. To submit, follow the instructions provided at http://server1.tepper. cmu.edu/md/electronic_submission.htm. Questions about the submission procedure can be transmitted to the Editorial Information System Manager, Stephen Spear, atss1f@andrew.cmu.edu, or to the Editor, William A. Barnett, at barnett@ku.edu.

Special Issues Submissions. The journal publishes special issues in its Supplements Series. Proposals for special issues should be sent to either of the journal's Special Issues Editors and should include a table of contents and one of more proposed guest editors.

Originality and Copyright. Manuscripts are accepted for review on the understanding that the same work has not been and will not be published nor is presently submitted for publication elsewhere. While under editorial review, it is the responsibility of the authors to keep the Editor informed about submissions, publication plans, and actual publication of related research or abstracts thereof in other outlets, including letters, journals, review publications, journals in other disciplines, conference proceedings, and published dissertations. It is further understood that all persons listed as authors have given their approval for the submis- sion of the paper and that any person cited as a source of personal communication has approved such citation; written authorization may be required at the Editor's discretion. Authors are responsible for obtaining written permission to publish material for which they do not own the copyright. A Copyright Transfer Agreement, with certain specified rights reserved by the author, must be signed and returned to the Editor by a senior author of accepted manuscripts, prior to publication. This is necessary to enable the publisher to ensure the wide distribution of the author's(s') work and the protection of both the author and the publisher under copyright law. Articles and other material published in Macroeconomic Dynamics represent the opinions of the authors and should not be construed to reflect the opinions of the Editor, Advisory Board, Editorial Board, or the Publisher.

Preparation of a Manuscript. The entire manuscript (including notes and references) should be produced as double spaced typescripton $8 \frac{1}{2} \times 11$-inch or A4 white paper, with wide margins to accommodate copyediting. The manuscript should be converted to a pdf for submission by upload-ing to the journal's server. The publisher asks that you provide a PDF file of the fi-nal version of your paper, together with a copy of the word processing source file in which the paper was written. Pages should be numbered consecutively. Page 1 should provide the article, author's(s') names (in the form preferred for publication, complete affiliation, phone, fax and e-mail num-bers (if available). At the bottom of Page 1 place any footnotes to the title or authors, indicated by superscripts *,**, etc. Page 2 should contain a proposed running head (abbreviated form of the title) of up to 40 characters, and the name and mailing ad-dress, telephone, fax and e-mail numbers of the author to whom proof's should be sent. Page 3 should contain a short abstract of the paper in less than 150 words. The abstract will appear at the head of the article when published in the journal. A list of three or four keywords or terms should also be included. The full text of the manuscript should begin on Page 4.

Equations. All equations should be typewritten and the numbers for displayed equations should be placed in parenthesis in the right margin. References to equations should simply use the form "(3)." Superscripts and subscripts should be typed clearly above and below the line, respectively. Theorem, lemma, and proposition statements should appear in italic print. End-of-proof signposts should appear as such: either $\mathbf{\square}$ or Q.E.D., typed in italics.
Authors are encouraged to use the following order for parentheses: $\{[(\ldots)]\}$.

Tables and Figures. If possible, the publisher asks that you include all graphics (charts, diagrams or other art work) at the end of the paper, indicating in the body of the paper where each graphic should appear. If it is not possible for you to include the graphics files in the word processor source code, you should upload the individual graphics files separately after you upload the PDF and source files for your paper.

References. References should be cited in the text by the author's last name and the date of publication. Complete bibliographic information for each citation should be included in the list of references. References should be typed in alphabetical order in the style of the following examples:

Monograph:

Stokey, Nancy L. and Robert E. Lucas, Jr. with Edward Prescott (1989) Re-cursive Methods in Economic Dynamics. Cambridge, MA: Harvard University Press Chapter in an Edited Volume:

Danthine, Jean-Pierre and John B. Donaldson (1995) Computing equilibria of nonoptimal economies. In Thomas F. Cooley (ed.), Frontiers of Business Cycle Research, pp. 65-97. Princeton, NJ: Princeton University Press.

Journal Article

Epstein, Larry G. and Stanley Zin (1989) Substitution, risk aversion and the temporal behavior of consumption and asset returns I: A theoretical framework. Econometrica 42, 937-969.

Article in Press:

Huang, He, Selahattin Imrohoroglu, and Thomas J. Sargent (in press) Two computational experiments to fund Social Security. Macroeconomic Dynamics.

Journal names should not be abbreviated. Footnotes. Where more that a simple source citation is called for, footnotes may be used. These should be numbered consecutively throughout the text and typed together at the end of the paper before the references. Source citations within footnotes follow the same style as citations within the text.

Copyediting and Proofreading. The publisher reserves the right to copyedit and proofread all articles for publication, but the corresponding author will receive page proofs for final proofreading. These should be checked and returned within five days of receipt. The publisher reserves the right to charge authors for excessive correction of non-typographical errors. 
MACROECONOMIC DYNAMICS

Volume 20, Number 8, December 2016

Contents

Special Issue on Technology Aspects in the Process of Development

Edited by Théophile T. Azomahou, Raouf Boucekkine, Pierre Mohnen, and Bart Verspagen

\section{ARTICLES}

Introduction to Macroeconomic Dynamics Special Issue on Technology

Aspects in the Process of Development

Théophile T. Azomahou, Raouf Boucekkine, Pierre Mohnen, and Bart Verspagen

Optimal Public Investment, Growth, and Consumption: Evidence from African Countries

Augustin Kwasi Fosu, Yoseph Yilma Getachew, and Thomas H. W. Ziesemer

How Important Is Innovation? A Bayesian Factor-Augmented

Productivity Model Based on Panel Data

Georges Bresson, Jean-Michel Etienne, and Pierre Mohnen

The Dynamics of Stagnation: A Panel Analysis of the Onset and Continuation of Stagnation

Richard Bluhm, Denis de Crombrugghe, and Adam Szirmai

Endogenous Fertility with a Sibship Size Effect

Elise S. Brezis and Rodophe Dos Santos Ferreira

Human Capital Productivity, Endogenous Growth, and Welfare:

The Role of Uncertainty

Mbaye Diene, Bity Diene, and Théophile T. Azomahou

Social Capital as an Engine of Growth: Multisectoral Modeling and Implications

Youyou Baende Bofota, Raouf Boucekkine, and Alain Pholo Bala

A Dynamic Model of Taxation, Corruption, and Public Investment in the Dynastic Cycle: The Case of Imperial China

Kenneth S. Chan and Jean-Pierre Laffargue

Connectivity and Economic Growth

Adriaan van Zon and Evans Mupela

Optimal Endogenous Growth with Natural Resources: Theory and Evidence

Manh-Hung Nguyen and Phu Nguyen-Van 